\title{
ANALISIS VITAMIN C DAN PROTEIN PADA BIJI BUAH LABU SIAM (Sechium edule)
}

\author{
Analysis of Vitamin C and Protein on Chayote (Sechium edule) Fruit Seeds
}

\author{
*Fadliya, Supriadi dan Anang Wahid M. Diah \\ Pendidikan Kimia/FKIP - Universitas Tadulako, Palu - Indonesia 94118 \\ Received 6 December 2017, Revised 4 January 2018, Accepted 5 February 2018
}

\begin{abstract}
Chayote seeds are found in the middle of the fruit which have flat structures and white. Those seeds has never been used. This study aimed to determine the levels of vitamin $C$ and protein in old chayote fruit seeds. The vitamin $C$ were analyzed using a UV-Vis spectrophotometer, while the protein were analyzed using the Kjeldahl method. Results showed that level of the vitamin $C$ in old fruit seeds was by $0.56 \%$, while the protein level obtained was by $0.81 \%$. This study concluded that old chayote fruit seeds contained protein and vitamin $C$ that can be used as a source of antioxidants and source of beneficial nutrition.
\end{abstract}

Keywords: Chayote, vitamin C, protein, Kjeldahl, UV-Vis.

\section{Pendahuluan}

Indonesia merupakan negara yang kaya akan kandungan alamnya terutama pada tumbuhan. Hal tersebut dapat dilihat dari keanekaragaman tumbuhan yang hidup berupa sayuran, buahbuahan, dan sebagainya. Kelimpahan dari sayuran ini banyak dijadikan bahan makanan sebagai sumber gizi yang dapat bermanfaat bagi manusia. Sumber gizi yang terdapat pada tumbuhan dapat berupa protein, lemak, karbohidrat, zat besi, kalsium, kalium dan sebagainya. Selain kandungan gizi tersebut di dalam sayuran biasanya terdapat vitamin yang diperlukan oleh manusia, seperti yang dikemukakan oleh Khomsam (2003) sayursayuran dan buah-buahan kaya akan kandungan vitamin, mineral, dan zat gizi lainnya yang dibutuhkan oleh tubuh manusia.

Sumber gizi dibutuhkan untuk membantu proses yang terjadi dalam tubuh. Di antara sumber gizi yang penting dalam tubuh yaitu protein dan vitamin C. Protein dapat diperoleh dari tumbuhan (protein nabati) dan dapat diperoleh dari hewan (protein hewani). Menurut Winarno (1986), protein berfungsi sebagai pengatur metabolisme, sebagai bahan bakar apabila keperluan energi tubuh tidak terpenuhi oleh lemak dan karbohidrat, dan sebagai zat pembangun jaringan-jaringan baru.

Buah labu siam merupakan salah satu sayuran yang mengandung berbagai macam vitamin. Salah satu vitamin yang terdapat pada buah labu siam yaitu vitamin C. Vitamin $\mathrm{C}$ adalah obat antioksidan kuat yang dapat digunakan secara topikal dalam dermatologi untuk mengobati dan mencegah perubahan terkait dengan photoaging (Telang, 2013). Vitamin C sebagai antioksidan alami secara luas yang dianjurkan dalam mengobati

${ }^{*}$ Correspondence

Fadlia

Program Studi Pendidikan Kimia, Fakultas Keguruan dan Ilmu Pendidikan, Universitas Tadulako

e-mail: fadliyaiya30@gmail.com

Published by Universitas Tadulako 2018 dan mendetoksifikasi (mengurangi sifat racun) (Khomson, 2010). Vitamin C sesuai fungsinya sebagai antioksidan dapat membantu memperlambat atau mencegah proses oksidasi. Zat ini secara nyata mampu memperlambat atau menghambat oksidasi zat yang mudah teroksidasi meskipun dalam konsentrasi rendah (Fachraniah, dkk., 2012).

Bagian dari tumbuhan labu siam yang dapat dikonsumsi selain buahnya yaitu daunnya. Daunnya dapat dijadikan sebagai lauk pauk seperti buahnya yang dijadikan sayuran. Kualitas dari buah labu siam akan menurun dengan adanya penyimpanan. Penyimpanan pasca panen buah labu siam pada suhu $25^{\circ} \mathrm{C}$ dapat menyebabkan berat buah menurun 2-5 kali lipat. Selama lima minggu penyimpanan buah yang terbuka dapat kehilangan $40 \%$ dari berat buah segar (Aung, dkk., 2015). Kandungan yang terdapat pada buah labu siam antara lain yaitu berupa natrium, zat besi, kalium, posforus, kalsium, lemak, protein, karbohidrat, serat, dan banyak mengandung air. Buah labu siam juga mengandung beberapa vitamin di antaranya yaitu vitamin $A$, vitamin $B$, dan vitamin C (Soedarya, 2009). Ekstrak pada buah labu siam menunjukan adanya kandungan alkaloid, flavonoid, saponin dan terpenoid (Sibi, dkk., 2013).

Berdasarkan kandungan yang ada, banyak dari buah labu siam selain dimanfaatkan sebagai sumber makanan juga dimanfaatkan sebagai sumber obat. Ekstrak buah labu siam memiliki kemampuan untuk menurunkan kadar glukosa darah (Putri, 2012). Air labu siam memiliki efek diuretik yang bermanfaat melancarkan buang air kecil. Labu siam juga bermanfaat mencegah penyakit jantung, stroke dan dapat meningkatkan kekebalan tubuh dengan adanya kandungan vitamin $\mathrm{B} 1$, vitamin $\mathrm{C}$, dan $\beta$-karoten (Soedarya, 2009).

Buah labu siam yang masih muda banyak dibeli masyarakat sebagai bahan olahan makanan. Ketika diolah buah labu siam dibersihkan dari kulitnya. 
Bagian daging buah labu siam diolah sebagai bahan baku olahan sayur dan dodol (Sari \& Sulandari, 2014). Berbeda halnya pada buah labu siam muda yang banyak dimanfaatkan sebagai bahan olahan makan dan sumber obat, buah labu siam tua kurang dimanfaatkan karena memiliki struktur kulit yang keras dan warna kulit buah yang sudah kekuningan.

Pemanfaatan dan penelitian yang dilakukan pada tanaman labu masih berkisar antara buah dan daun. Mengingat kandungan yang terdapat pada buah labu siam banyak memiliki manfaat, sehingga perlu dilakukan penelitian lebih lanjut mengenai kandungan yang ada pada bagian lainnya seperti pada bagian biji. Perlunya dilakukan penelitian pada bagian biji, agar informasi mengenai kandungan gizi yang terdapat pada biji dapat bermanfaat bagi masyarakat dan menjadi salah satu alternatif bahan pangan.

Tulisan ini mendeskripsikan analisis kadar vitamin $C$ dan protein yang terdapat pada biji buah labu siam tua (Sechium edule).

\section{Metode}

Alat yang digunakan dalam penelitian adalah neraca analitik ( $A N D G R-200)$, peralatan gelas, kertas saring, blender, mikropipet, spektrofotometer SpectroDirect RS232 serial No: 1257060900344, spektrofotometer UV-IS Perkin Elmer Lamda 25, dan gerhardt Kjeldahltherm.

Bahan yang digunakan antara lain adalah biji buah labu siam tua yang diperoleh dari pasar tradisional Masomba Sulawesi Tengah, aquades, vitamin $\mathrm{C}$ murni, etanol p.a. (J.T. $B A K E R)$, biji tablet Kjeldahl, dan larutan $\mathrm{H}_{2} \mathrm{SO}_{4}\left(J H D^{T M}\right)$.

Biji labu siam dipisahkan dari bagian buahnya dengan membelah bagian tengah labu siam. Biji yang diambil berwarna putih pipih yang teletak pada bagian tengah buah labu siam. Biji buah labu siam yang telah dipisahkan kemudian ditimbang 10 gram. Sampel dipotong menjadi ukuran yang lebih kecil dan dimasukan ke dalam oven selama 24 jam pada suhu $50{ }^{\circ} \mathrm{C}$. Sampel yang telah kering selanjutnya diblender hingga halus.

\section{Analisis kadar vitamin $C$}

$25 \mathrm{mg}$ vitamin $\mathrm{C}$ murni dilarutkan dalam labu ukur $25 \mathrm{~mL}$ menggunakan etanol $96 \%$ sampai tanda batas. Larutan induk vitamin C diukur serapannya pada panjang gelombang 200-400 nm untuk mengetahui panjang gelombang maksimum.

Larutan standar vitamin $\mathrm{C}$ dengan seri konsentrasi 50, 100, 150, 200, dan $250 \mathrm{mg} / \mathrm{L}$ dibuat dari larutan induk vitamin C $1000 \mathrm{mg} / \mathrm{L}$. Selanjutnya larutan standar diukur serapannya menggunakan spektrofotometer UV-Vis pada panjang gelombang maksimum dan dibuat kurva standar vitamin $\mathrm{C}$ untuk menentukan persamaan kurva standar (regresi linier).

Sampel 0,025 gram diekstrak dengan menggunakan etanol $96 \%$ berkali-kali hingga semua vitamin $\mathrm{C}$ terekstrak, kemudian disaring menggunakan kertas saring. Filtrat yang diperoleh, kemudian diukur serapannya menggunakan spektrofotometer UV-Vis pada panjang gelombang maksimum. Konsentrasi vitamin $\mathrm{C}$ pada sampel ditentukan berdasarkan persamaan kurva standar (regresi linier).

1 gram sampel biji buah labu siam tua dimasukan dalam labu Kjeldahl. Tablet Kjeldahl 1 butir dan larutan asam sulfat pekat $10 \mathrm{~mL}$ ditambahkan dalam labu Kjeldahl. Semua bahan pada labu Kjeldahl didestruksi sampai mendidih dan larutan menjadi jernih. $50 \mathrm{~mL}$ aquades ditambahkan lalu larutan didinginkan hingga suhu kamar dan diambil $10 \mathrm{~mL}$ filtrat. Kadar nitrogen total ditentukan menggunakan Spectrodirect dengan mengambil sampel filtrat sebanyak $10 \mathrm{~mL}$ Pengulangan perlakuan dilakukan sebanyak tiga kali.

Analisis kadar vitamin C pada biji buah labu siam tua (Sechium edule) ditentukan menggunakan spektrofotometri UV-Vis. Nilai absorbansi yang diperoleh dimasukan dalam persamaan kurva standar (regresi linier) vitamin C untuk mengetahui konsentrasi vitamin $\mathrm{C}$ pada sampel dengan menggunakan rumus (Ismayanti, 2013).

$$
\text { \% Vitamin C }=\frac{x\left(\frac{m g}{L}\right) X \text { volume }(L)}{\text { berat sampel }(m g)} X 100 \%
$$

Analisis kadar protein pada biji buah labu siam tua (sechium Edule) ditentukan dengan menggunakan metode Kjeldahl dengan cara destruksi, kemudian dimasukan dalam alat Spektrodirect untuk menentukan nilai nitrogen total dan $\% \mathrm{~N}$ pada sempel. Kadar nitrogen yang diperoleh digunakan untuk menentukan kadar protein pada sampel dengan menggunakan rumus (Sudarmadji, 1989).

$\%$ Protein $=\frac{N x \text { Faktor pengenceran } x 6,25 \times \text { jumlah } m L \text { sampel }}{\text { Berat Sampel }} \times 100 \%$

\section{Hasil dan Pembahasan}

\section{Penentuan kurva standar vitamin $C$}

Penentuan kurva standar vitamin C menggunakan absorbansi yang diperoleh dari hasil pengukuran dengan menggunakan variasi larutan standar yang dibuat. Absorbansi yang diperoleh, diukur menggunakan instrumen spektrofotometer UV-Vis pada panjang gelombang maksimum yang diperoleh pada larutan induk vitamin C. Panjang gelombang maksimum yang digunakan pada penelitian ini yaitu $270 \mathrm{~nm}$. Hasil pengukuran absorbansi larutan standar vitamin $\mathrm{C}$ dapat dilihat pada Tabel 1. Absorbansi yang diperoleh selanjutnya dibuat dalam bentuk kurva, dengan nilai $\mathrm{Y}$ adalah absorbansi larutan standar vitamin $\mathrm{C}$ dan $\mathrm{X}$ adalah konsentrasi larutan vitamin $\mathrm{C}$.

\section{Penentuan kadar vitamin $C$ dan protein}

Hasil penelitian kadar vitamin $C$ dan protein pada biji buah labu siam tua (Sechium edule) diperoleh kadar vitamin $\mathrm{C}$ sebesar $0,56 \%$ dan kadar protein sebesar $0,81 \% \pm 0,11$. 
Tabel 1. Hasil pengukuran absorbansi larutan baku asam askorbat secara Spektrofotometri UVVisible $(\lambda=270 \mathrm{~nm})$

\begin{tabular}{cc}
\hline \multicolumn{2}{c}{ Kurva Standar vitamin C } \\
Konsentrasi $(\mathrm{mg} / \mathrm{L})$ & Absorbansi \\
\hline 50 & 0,0603 \\
100 & 0,4010 \\
150 & 0,7019 \\
200 & 1,0181 \\
250 & 1,2301 \\
\hline
\end{tabular}

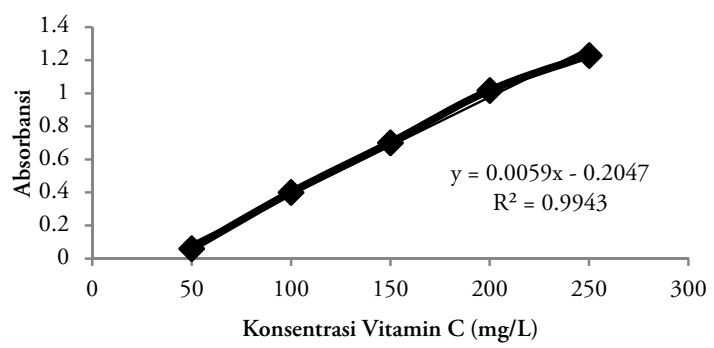

Gambar 1. Kurva Standar Hubungan antara Konsentrasi vitamin C dengan Absorbansi

Analisis Kadar Vitamin C

Kadar vitamin $C$ pada biji buah labu siam tua dilakukan dengan metode spektrofotometri UVVis. Analisis kadar vitamin $\mathrm{C}$ biji buah labu siam tua diawali dengan membuat larutan induk vitamin C $1000 \mathrm{mg} / \mathrm{L}$ dengan menggunakan pelarut etanol 96\%. Larutan induk vitamin C 1000 ppm digunakan untuk membuat deret standar vitamin $\mathrm{C}$. Deret standar vitamin $\mathrm{C}$ yang dibuat yaitu 50, 100, 150, 200, dan $250 \mathrm{mg} / \mathrm{L}$. Dari deret standar vitamin $\mathrm{C}$, diukur absorbansi pada panjang gelombang maksimum yang diperoleh pada larutan induk vitamin C. Panjang gelombang maksimum menggunakan spektrofotometer UV-Vis dilakukan pada rentang 200-400 nm, rentang ini dipilih karena molekulmolekul ikatan rangkap yang memiliki energi eksitasi rendah menimbulkan penyerapan daerah UV dekat (Wardani, 2012). Panjang gelombang maksimum yang diperoleh pada larutan induk vitamin $C$ yaitu $270 \mathrm{~nm}$.

Tabel 1 menunjukan persamaan linier dari standar vitamin $\mathrm{C}$ dengan menggunakan pelarut etanol $96 \%$ yaitu $y=0,0059 x-0,2047$ dengan nilai regresi linier $\left(\mathrm{R}^{2}\right)$ yaitu 0,9943 . Rentang nilai pada daerah ini menunjukan daerah respon linier suatu validasi metode penetapan kadar senyawa dalam suatu analit. Nilai $\mathrm{R}$ yang diperoleh mendekati nilai 1 dimana terdapat korelasi yang positif antara konsetrasi vitamin $\mathrm{C}$ dengan serapan, yang artinya peningkatan konsentrasi vitamin $\mathrm{C}$ akan mengakibatkan peningkatan nilai absorbansi yang terbaca pada spektrofotometer UV-Vis secara linier. Penggunaan pelarut etanol digunakan karena sifatnya tidak beracun, tidak berbahaya, memiliki titik didih yang rendah sehingga cenderung aman, dan sifatnya yang universal yang dapat melarutkan senyawa yang bersifat polar -
$\mathrm{OH}$ dan bersifat nonpolar $\mathrm{CH}_{2} \mathrm{CH}_{3}$ (Febrizky dkk., 2014).

Biji buah labu siam tua yang telah terekstrak diukur serapannya menggunakan instrumen spektrofotometer UV-Vis pada panjang gelombang maksimum dan diperoleh nilai absorbansi biji buah labu siam tua yaitu 0,1289 . Nilai absorbansi yang telah diperoleh tersebut, dapat digunakan untuk menentukan konsentrasi vitamin $\mathrm{C}$ sampel dengan menggunakan persamaan linier yang diperoleh pada kurva standar vitamin $\mathrm{C}$ (Gambar 1). Konsentrasi vitamin $\mathrm{C}$ biji buah labu siam tua yang diperoleh yaitu sebesar $56,542 \mathrm{mg} / \mathrm{L}$, sehingga diperoleh kadar vitamin $\mathrm{C}$ biji buah labu siam tua yaitu $0,56 \%$ dalam 0,025 gram sampel. Menurut Saade (1996) dalam biji buah labu siam tidak diperoleh adanya kandungan vitamin C. Jika dibandingkan hasil yang terdapat pada literatur dan hasil dari penelitian ini memiliki perbedaan untuk hasil analisis kadar vitamin C. Hal tersebut dapat terjadi dikarenakan oleh beberapa faktor antara lain kondisi lingkungan tempat tumbuh yang mempengaruhi kandungan yang terdapat pada biji buah labu siam dan juga perbedaan sampel yang digunakan dimana sampel yang digunakan pada penelitian ini yaitu biji pada buah labu siam yang sudah tua.

Vitamin C merupakan salah satu sumber antioksidan yang larut dalam air, mudah diperoleh, dan banyak dikonsumsi masyarakat. Vitamin C mudah teroksidasi karena senyawa mengandung gugus fungsi hidroksi $(\mathrm{OH})$ yang sangat reaktif dengan adanya oksidator gugus hidroksi akan teroksidasi menjadi gugus karbonil. Proses oksidasi akan terhambat bila vitamin $\mathrm{C}$ berada dalam keadaan suhu rendah (Harper, dkk., 1986). Secara umum reaksi oksidasi vitamin $\mathrm{C}$ ada dua macam yaitu proses oksidasi spontan dan proses oksidasi tidak spontan. Proses oksidasi spontan adalah proses oksidasi yang terjadi tanpa menggunakan enzim atau katalisator. Sedangkan proses oksidasi tidak spontan yaitu reaksi yang terjadi dengan adanya penambahan enzim atau katalisator, misalnya enzim glutation (Andarwulan \& Koswara, 1992).

\section{Analisis kadar protein}

Analisis kadar protein pada biji buah labu siam tua menggunakan metode Kjeldahl. Proses destruksi pada sampel dilakukan dengan menambahkan asam kuat pekat (asam sulfat) ke dalam sampel dan proses pemanasan pada suhu tinggi, sehingga menghasilkan larutan berwarna jernih yang mengandung amonium sulfat. Banyaknya sampel yang digunakan pada proses ini yaitu 1 gram. Tahap destruksi ini dilakukan agar seluruh karbon dan hidrogen teroksidasi dan nitrogen diubah menjadi amonium sulfat. Untuk mempercepat proses destruksi, ditambahkan tablet Kjeldahl yang mengandung kalium sulfat, tembaga sulfat, dan titanium dioksida. Kalium sulfat berfungsi meningkatkan titik didih asam sulfat sedangkan untuk tembaga sulfat dan titanium 
dioksida berfungsi sebagai katalisator (Andarwulan, dkk., 2011).

Sampel hasil destruksi yang berwarna jernih selanjutnya dianalisis kandungan nitrogennya menggunakan instrumen spektrofotometer Spektrodirect. Analisis sampel yang dilakukan harus menggunakan larutan berwarna dan bening. Larutan berwarna dan keruh harus didestruksi terlebih dahulu agar diperoleh larutan jernih yang siap dianalisis. Proses destruksi yang sebelumnya dilakukan, bertujuan untuk menghilangkan kandungan ion lain yang dapat mengganggu proses analisis dan akurasi pembacaan alat spektrofotometer, sehingga kesalahan saat pembacaan dapat ditekan seminimal mungkin (Mazaya, dkk., 2013). Hasil analisis kuantitatif yang diperoleh pada spectrodirect berupa kadar nitrogen yang terdapat pada sampel. Hasil tersebut selanjutnya ditentukan kadar nitrogennya. Kadar nitrogen yang diperoleh, dikonversi menjadi kadar protein dengan mengalikannya dengan faktor konversi yang sesuai. Faktor konversi yang digunakan pada penelitian ini yaitu 6,25, nilai koversi tersebut digunakan kerena umumnya protein alamiah mengandung unsur $\mathrm{N}$ rata - rata $16 \%$, sehingga 1 gram nitrogen berasal dari 6,25 gram protein (dalam protein murni) (Andarwulan, dkk., 2011).

Kadar protein biji buah labu siam sebesar $0,81 \%$ dalam 1 gram sampel. Standar deviasi yang diperoleh pada penelitian ini $\pm 0,11 \%$. Standar deviasi yang diperoleh pada penelitian ini menunjukan bahwa metode analisis mempunyai presisi yang cukup baik. Presisi merupakan tingkat kesesuaian antara hasil analisis individual jika prosedur dilakukan berulang kali terhadap sampel ganda atau beberapa sampel homogen. Hasil yang diperoleh dari penelitian dengan hasil yang terdapat pada literatur pada biji buah labu siam terdapat perbedaan, dimana pada literatur diperoleh kadar protein yaitu sebesar 5,5\%. Perbedaan hasil penelitian yang diperoleh dengan literatur dapat terjadi karena dipengaruhi oleh beberapa faktor antara lain tempat tumbuh dari tanaman tersebut dan perbedaan sampel yang dingunakan pada penelitian ini, dimana sampel yang digunakan yaitu biji pada buah labu siam yang sudah tua (Saade, 1996).

Protein dalam sayur-sayuran dan buah-buahan berperanan sebagai bahan struktural dari membran sel dan komponen inti sel serta sebagai biokatalis (enzim). Perhitungan protein total pada sayursayuran dan buah-buahan sebenarnya belum menggambarkan kandungan protein sesungguhnya. Hal tersebut karena peneraan protein total dengan menera $\mathrm{N}$ yang ada dalam bahan, walaupun $\mathrm{N}$ tersebut $\mathrm{N}$ non protein. Kandungan protein dalam sayur-sayuran dan buah-buahan kecil, tetapi tersusun oleh jenis asam amino yang cukup lengkap (Pujimulyani, 2009).

Beberapa protein sangat tahan terhadap denaturasi, sedangkan protein-protein lain tidak tahan terhadap denaturasi. Denaturasi suatu protein merupakan hilangnya sifat-sifat struktur lebih tinggi oleh terkacaunya ikatan hidrogen dan gaya-gaya sekunder lain yang mengutuhkan molekul itu. Akibat dari suatu denaturasi adalah hilangnya banyak sifat biologis protein itu. Faktor yang menyebabkan denaturasi pada protein antara lain yaitu perubahan temperatur, perubahan $\mathrm{pH}$, radiasi, zat pengoksidasi atau pereduksi dan pelarut (Fessenden \& Fessenden, 1982).

\section{Kesimpulan}

Kadar vitamin C pada biji buah labu siam tua yang diambil dari pasar tradisional Masomba Palu, Sulawesi Tengah menggunakan spektrofotometer UV-Vis yaitu $0,56 \%$ dan kadar protein dengan metode Kjeldahl yaitu $0,81 \% \pm 0,11 \%$.

\section{Ucapan Terima Kasih}

Ucapan terimakasih penulis sampaikan kepada seluruh laboran laboratorium kimia Fakultas Keguruan dan Ilmu Pendidikan Universitas Tadulako yang telah memberikan bimbingan dan masukan dalam menyelesaikan penelitian ini.

\section{Referensi}

Andarwulan, N. \& Koswara, S. (1992). Kimia vitamin. Jakarta: Rajawali.

Andarwulan, N., Kusnandar, F. \& Herawati, D. (2011). Analisis pangan. Jakarta: Dian Rakyat.

Aung, L. H., Harris, C. M., Rij, R. E. \& Brown, J. W. (2015). Postharvest storage temperature and film wrap effects on quality of chayote, Sechium edule Sw. Journal of Horticultural Science, 71(2), 297-304.

Fachraniah, Kurniasih, E. \& Novilasi, D. T. (2012). Ekstraksi antioksidan dari daun kari. Jurnal Reaksi (Journal of Science and Technology), 10(21), 35-44.

Febrizky, S., Mario, A. D. \& Aziz, T. (2014). Pengaruh jenis pelarut terhadap persen yield alkaloid dari daun salam india (muraya keonigii). Teknik Kimia, 2(20), 1-6.

Fessenden, R. J. \& Fessenden, J. S. (1982). Kimia organik. Edisi ketiga jilid 2. Jakarta: Erlangga.

Harper, L. J., Deaton, B. J., Driskel, J. A. \& Suhardjo. (1986). Pangan gizi dan pertanian. Jakarta: Universitas Indonesia.

Ismayanti. (2013). Kajian kadar fenolat total dan aktivitas antioksidan jus kulit buah semangka (Citrullus lanatus). Online Journal of Natural Science, 2(2), 100-110.

Khomsan, A. (2003). Teknik pengukuran pengetahuan gizi. Bogor: Departemen Gizi Masyarakat dan Sumber Daya Keluarga, Fakultas Pertanian, IPB.

Khomson, A. (2010). Pangan dan gizi untuk kesehatan. Jakarta: PT. Raja Grafindo Persada.

Mazaya, M., Susatyo, E. B. \& Prasetya, A. T. (2013). Pemanfaatan tulang ikan kakap untuk meningkatkan kadar fosfor pupuk cair limbah 
tempe. Indonesian Journal of Chemical Science, 2(1), 7-11.

Pujimulyani, D. (2009). Teknologi pengolahan sayur-sayuran dan buah-buahan. Yogyakarta: Graha Ilmu.

Saade, R. L. (1996). Chayotte (sechium edule) international plant genetic resources institute. [Online]. Tersedia: http://pdf.usaid.gov/pdf_docs/PNACH876.pd f. [14 Januari 2016].

Sari, S. M. W. \& Sulandari, L. (2014). Pengaruh jumlah asam sitrat dan agar-agar terhadap sifat otganoleptik manisan bergula pure labu siam (Sechium edule). e-Journal Boga, 03(1), 100110.

Sibi, G., Kaushik, K., Dhananjaya, K., Ravikumar, K. R. \& Mallesha, H. (2013). Antibacterial activity of sechium edule (Jacq.) swartz against gram negative food borne bacteria. Advances in Applied Science Research, 4(2), 259-261.

Soedarya, A. P. (2009). Agribisnis labu siam. Bandung: CV. Pustaka Grafika.

Sudarmadji, S. (1989). Analisa bahan makanan dan pertanian. Yogyakarta: Penerbit Liberti.

Telang, P. S. (2013). Vitamin C in dermatology. Indian Dermatology Online Journal, 4(2), 143146.

Wardani, L. (2012). Validasi metode analisis dan penentuan kadar vitamin c pada minuman buah kemasan dengan spektrofotometri uv-vis. Jakarta: Universitas Indonesia.

Winarno, F. G. (1986). Kimia pangan dan gizi. Jakarta: PT. Gramedia. 